\title{
The Influence of New Media on College Students' Ideological and Political Education and the Countermeasures
}

\author{
Hui Ai* \\ Xi'an Aeronautical University, Xi'an 710077, Shaanxi Province, China
}

\begin{abstract}
In recent years, new media has been booming in our country. College students can learn about everything happening in the world in real time through the Internet, which speeds up their understanding and acceptance of information. However, due to the relatively simple environment the college students grew up in, the incomplete formation of their own values, and the mixture of information on the Internet, learning through the Internet can have adverse effects on the psychology of college students. Based on the in-depth and systematic exploration of the current situation on ideological and political education in colleges and universities, this paper analyzes the existing problems of ideological and political education in colleges and universities under the influence of new media. In view of these problems, an in-depth study on the innovation of ideological and political education in contemporary colleges and universities was conducted, and this paper puts forward relevant improvement methods for the discussion and exchange of the industry.
\end{abstract}

Keywords: New media; College student; Ideological and political education; Promotion of information technology

Publication date: May, 2021; Publication online: 31 May, 2021

*Corresponding author: Hui Ai, timmon@163.com

\section{Introduction}

In this new era, the content of ideological and political teaching in universities should not be textbook limited, instead, the complexity and variety of the human societies should also be given emphasis. Since the things that students come in contact with becomes more complex after entering university, colleges and universities should fully rely on the new media information technology in the courses of ideological and political education. Also, the ideological and political teaching methods should meet the contemporary requirements.

\section{Concept and Types of New Media}

In recent years, new media has developed rapidly, as it is different from the traditional communication tools. It has the characteristics of significant personalized innovation, and can understand the needs of people for information. While new media brings us convenience, it also gradually makes us more dependent on it. At present, with the increase of people's needs, new media has developed a variety of concepts and types, which are more updated and professional than traditional media. Also, it adapts better to the practical needs of information development in the current new era. However, the new media not only influences our daily life, but also our work productivity to a great extent. Through new media, we have developed a new way of brand promotion, which has brought great help to enterprises and products to the market.

\section{Influence of New Media on College Students' Ideological and Political Education}

\subsection{Positive impact}

\subsubsection{Knowledge source}

In the process of traditional education, college students' knowledge source is mainly derived from 
teachers' oral and psychological teachings. In the new media era, students can easily obtain the knowledge and information they want through the Internet. The application of new media has greatly enriched the channels for college students to obtain information, and students can also develop their own areas of focus according to their own interests $^{[1]}$.

\subsubsection{Psychology}

New media has the characteristics of easy to use, high-speed information transmission, no time and space restrictions, so it is preferred by college students. Moreover, the major network platforms have become an important place for college students to vent their emotions, exchange ideas, and learn from each other. College students use new media channels to start their own communication circle where they display their emotional frustrations and feelings. This conducive growth in new media communication channels prevents psychological issues in college students.

\subsection{Negative impact}

\subsubsection{Information gap}

In the ideological and political education in colleges and universities, educators often have solid theoretical knowledge, but lack of contact with updated information. In the long run, there will be a large information gap between students and teachers. The development of new media gives college students more freedom and independence in obtaining information, so they will no longer rely on the traditional channels like teachers to provide them with information, thus challenging the dominant position of ideological and political educators.

\subsubsection{Lack of legal norms}

Along with the development of new media technology, the traditional education environment has become more complex and diverse. The main reason is that the field of new media in China is still an emerging industry, and the country has no perfect legal norms for new media. This leads to the dissemination of positive and negative content from the current new media. Many college students are easily influenced by negative content and become the disseminators of negative influences because they are not mature enough. In this environment, it greatly increases the difficulty of ideological and political education of college students. Compared with the traditional education environment, ideological and political educators in colleges and universities need to create new teaching methods and meet the contemporary needs.

\section{Countermeasures of College Students' Ideological and Political Education Under the Influence of New Media \\ 4.1 Building a multi-level ideological and political education platform}

Colleges and universities can build a new multilevel ideological and political education platform in campus, as an improvised traditional learning using advantages of new media. The construction of the platform should focus on cultivating students' outlooks by enriching and optimizing the knowledge of traditional culture as well as enhancing students' sense of identity with excellent traditional culture. In addition, we should also emphasize the importance and popularize the subject and object of education on the platform to ensure its educational effect. At the same time, the principle of rich and colorful content production should be adopted to meet the aesthetic taste of contemporary college students on the basis of ensuring the educational effect, as well as to strengthen the diversity and interaction of the platform $^{[2]}$.

\subsection{Enriching the three-dimensional means of ideological and political education}

In the new era, ideological and political education is complex and diverse. Colleges and universities should make rational use of the new media platform, take control of the opportunity, give full involvement to the interactivity of new media, establish a good communication mode, and strengthen college students' understanding of basic theoretical knowledge. At the same time, we can also rely on the new media to build online and offline ideological and political education modes, 
and effectively reduce the gaps among students caused by the differences in identity and family background. The construction of three-dimensional education channels in new media network can renew and increase opportunities of ideological and political education $^{[3]}$.

\section{Conclusion}

The ideological and political education of college students is an important part and content of China's basic education. Colleges and universities should also attach great importance to the construction and development of ideological and political education of college students. Also, the effective operation of network and traditional media in ideological and political education should be constantly innovated, and the innovative practice of ideological and political education of college students should be promoted. In the collaboration of new media with ideological and political courses, teachers in colleges and universities must adapt to the development needs of the new internet era, constantly update their ideological and political education theory, improve education management methods, improve education management ability and constantly enhance the effect of ideological and political education management.

\section{Disclosure statement}

The author declares no conflict of interest.

\section{References}

[1] (2020). Research on the influence of new media environment on College Students' Ideological and political education and countermeasures. Friends of The Humanities,6 (6): 78.

[2] Shang, M.D(2020). The Influence of New Media on the Ideological and Political Education of College Students and the Exploration of Countermeasures. Industry and Technology Forum,19(10): 93-94.

[3] Que. L.Y(2020). Research on the Current Situation of College Students' Ideological and Political Education in the New Media Era and its Promotion Countermeasures. Journal of Heilongjiang Teacher Development Institute,(5): 110-112. 